Short Communication

\title{
Study of Effect of Batteries Capacity on Probability of Thermal Runaway Occurrence
}

\author{
Nataliya N. Yazvinskaya ${ }^{1}$, Nikolay E. Galushkin ${ }^{1, *}$, Dmitriy N. Galushkin ${ }^{1}$, Inna A. Galushkina ${ }^{2}$ \\ ${ }^{1}$ Don State Technical University, Laboratory of electrochemical and hydrogen energy, 147 \\ Shevchenko Street, Town of Shakhty, Rostov Region, Russia, 346500. \\ ${ }^{2}$ Southern Federal University, Novoshakhtinsk branch, 2 Oktiabria Street, Town of Novoshakhtinsk, \\ Rostov Region, Russia, 346900. \\ *E-mail: galushkinne@mail.ru
}

doi: $10.20964 / 2016.10 .42$

Received: 15 July 2016 / Accepted: 11 August 2016 / Published: 6 September 2016

In this study, it was shown that an occurrence probability of a thermal runaway in nickel-cadmium batteries with sintered electrodes falls down with decrease of batteries capacity, while other parameters necessary for thermal runaway process occurrence such as dendrites density on cadmium electrode and gravimetric capacity of a hydrogen accumulation in electrodes do not depend on the batteries capacity.

Keywords: thermal runaway, battery, nickel-cadmium

\section{$\underline{\text { FULL TEXT }}$}

(C) 2016 The Authors. Published by ESG (www.electrochemsci.org). This article is an open access article distributed under the terms and conditions of the Creative Commons Attribution license (http://creativecommons.org/licenses/by/4.0/). 